\title{
Associated plasma protein during the first trimester of pregnancy and pregnancy outcomes
}

\section{Vennapusa Rama Devi*}

Department of Obstetrics and Gynecology, Fathima Institute of Medical Sciences, Kadapa, Andhra Pradesh, India

Received: 05 January 2018

Accepted: 08 January 2018

\section{*Correspondence:}

Dr. Vennapusa Rama Devi,

E-mail: ramadevi1963@gmail.com

Copyright: () the author(s), publisher and licensee Medip Academy. This is an open-access article distributed under the terms of the Creative Commons Attribution Non-Commercial License, which permits unrestricted non-commercial use, distribution, and reproduction in any medium, provided the original work is properly cited.

\begin{abstract}
Background: Newborns are perhaps the most vulnerable population the world over. Preterm or babies born too early, less than 37 weeks gestation, are particularly at risk. Objective of present study were to determine the strength of relationship between PAPP-A concentrations using our own reference range and rates of idiopathic preterm delivery.

Methods: A retrospective cohort study was conducted on consecutive singleton pregnancies undergoing firsttrimester screening for fetal Down syndrome between 11 weeks and 14 weeks of pregnancy.

Results: 500 patients in first trimester of pregnancy were selected in this study. 400 patients were found to have normal levels and were followed up till delivery. 20 patients developed preterm labour. Out of 100 patients who had low PAPP-A level, 35 patients had developed preterm labour. 15 patients out of 400 normal patients developed foetal growth retardation, 13 out of 100 low patients had foetal growth retardation. 5 out 400 normal patients developed PIH and no still birth was seen in normal patients. 15 out of 100 low patients had PIH and 2 patients had still birth. Most of the patients had asymmetrical FGR which concludes that there might be increased utero-placental resistance because of foetal growth restriction.

Conclusions: In the first trimester of pregnancy, PPP-A level is an important predictor of outcome of obstetrics. A low level of PAPP-A is useful in indicating the risk of pre-term delivery and chance of PIH development.
\end{abstract}

Keywords: First-trimester screening, Idiopathic preterm delivery, Pregnancy-associated plasma protein A

\section{INTRODUCTION}

Newborns are perhaps the most vulnerable population the world over. Preterm or babies born too early, less than 37 weeks gestation, are particularly at risk. ${ }^{1}$ Currently, prematurity is the leading cause of death among children under five around the world, and a leading cause of disability and ill health later in life. ${ }^{2}$ In India, 3,341,000 babies are born too soon each year and 361,600 children under five die due to direct preterm complications. Almost 1 million children die each year due to complications of preterm birth (2013). In India, out of 27 million babies born every year (2010 data), 3.5 million babies born are premature. Newborn deaths (those in the first month of life) account for 40 percent of all deaths among children under five years of age. ${ }^{3}$ Since firsttrimester serum marker screening for fetal Down syndrome has been used worldwide, it has been shown that an unexplained low levels of pregnancy-associated plasma protein A (PAPP-A), a component of serum markers, is strongly related to preterm delivery and other adverse outcomes of pregnancy. ${ }^{4}$ First-trimester screening for Down syndrome, PAPP-A, and beta-human chorionic gonadotropin $(\beta-h C G)$, is routinely offered in our geographical regions. Therefore, it is possible that PAPPA levels may help identify pregnant women at a higher risk of preterm delivery. As already known, PAPP-A concentrations in maternal serum vary depending on 
several factors, including maternal size and ethnicity, and each geographical region should have its own reference ranges. ${ }^{5}$ Moreover, in most previous studies, other predisposing factors of preterm birth were not strictly controlled. Therefore, we conducted this study to determine the strength of relationship between PAPP-A concentrations using our own reference range and rates of idiopathic preterm delivery.

\section{METHODS}

A retrospective cohort study was conducted from January 2013-2016 on consecutive singleton pregnancies undergoing first-trimester screening for fetal Down syndrome between 11 weeks and 14 weeks of pregnancy. All pregnant women attending antenatal care at our hospital have routinely been offered first-trimester Down syndrome screening, regardless of maternal age.

Baseline demographic data of the women, including maternal age, parity, maternal body weight, ethnic origin, smoking habits or illicit drug use, as well as medical complications were assessed and recorded in the protocol form at the time of blood sample collection. The collected blood samples were immediately transferred to the laboratory and were centrifuged for serum separation.

The bioassays for PAPP-A and free $\beta$-hCG were performed. The absolute concentrations of serum PAPP$\mathrm{A}$, and free $\beta$-hCG. A combined risk of 1:500 or greater was considered as positive, and karyotyping would be offered. From database records complete outcome information as PAPP-A concentrations, gestational age at delivery, medical and obstetric complications, and fetal and pregnancy outcomes. The women were enrolled in our screening program with written informed consent.

\section{Inclusion criteria}

Singleton pregnancies, 11 weeks and 14 weeks of pregnancy based on the last menstrual period and ultrasound examination for crown-rump length in the first trimester, no history of previous spontaneous preterm birth; and no medical or obstetric complications.

\section{Exclusion criteria}

Late-occurring pregnancy complications such as preeclampsia, placental abruption, placenta previa, Fetal anomalies, fetal chromosomal abnormalities, incomplete data, loss to follow-up, or unavailability of pregnancy outcomes; and preterm births indicated. The recruited women were assigned to two groups: one group with normal PAPP-A levels ( $\geq 10$ th percentile; equivalent to $0.53 \mathrm{MoM})$ and the other group with low PAPP-A levels ( $<10$ th percentile). The main outcome was the rate of spontaneous preterm births in the two groups. Preterm births were classified into three groups: birth before 37 complete weeks, 34 complete weeks, and 32 complete weeks of gestation. This study was ethically approved by the institute review boards.

\section{Statistical analysis}

The statistical analysis was performed using SPSS version 17.0. Descriptive statistics were used to compare baseline characteristics between the two groups, using Student $t$ tests for continuous variables and chi-square. A $\mathrm{p}$ value of $<0.05$ was considered statistically significant. Relative risk for preterm birth for pregnancy with a low PAPP-A level was calculated, as well as $95 \%$ confident interval. A receiver-operator curve was also constructed to determine the diagnostic performance of low PAPP-A levels in predicting preterm birth.

\section{RESULTS}

500 patients in first trimester of pregnancy were selected in this study.

Table 1: Comparison between the outcomes (preterm labour) in relation to PAPP-A levels.

\begin{tabular}{|lll|}
\hline PAPP-A level & No. of patients & Pre-term labour \\
\hline $\begin{array}{l}\text { Normal }(>0.5 \\
\text { MoM })\end{array}$ & 400 & 20 \\
\hline Low $(<0.5$ MoM) & 100 & 35 \\
\hline
\end{tabular}

Table 1 shows that 400 patients were found to have normal levels and were followed up till delivery. 20 patients developed preterm labour. Out of 100 patients who had low PAPP-A level, 35 patients had developed preterm labour.

Table 2: Comparison between the foetal growth retardation of in relation to PAPP-A levels.

\begin{tabular}{|l|l|l|}
\hline PAPP-A level & $\begin{array}{l}\text { No. of } \\
\text { patients }\end{array}$ & $\begin{array}{l}\text { Foetal growth } \\
\text { retardation }\end{array}$ \\
\hline Normal $(>0.5 \mathrm{MoM})$ & 400 & 15 \\
\hline Low $(<0.5 \mathrm{MoM})$ & 100 & 13 \\
\hline
\end{tabular}

Table 2 shows that 15 patients out of 400 normal patients developed foetal growth retardation, 13 out of 100 low patients had foetal growth retardation.

Table 3: Comparison between the PIH and still birth in relation to PAPP-A levels.

\begin{tabular}{|llll|}
\hline PAPP-A level & $\begin{array}{l}\text { No. of } \\
\text { patients }\end{array}$ & PIH & $\begin{array}{l}\text { Still } \\
\text { birth }\end{array}$ \\
\hline Normal $(>0.5 \mathrm{MoM})$ & 400 & 5 & Nil \\
\hline Low $(<0.5 \mathrm{MoM})$ & 100 & 15 & 2 \\
\hline
\end{tabular}

Table 3 shows that 5 out 400 normal patients developed $\mathrm{PIH}$ and no still birth was seen in normal patients. 15 out of 100 low patients had PIH and 2 patients had still birth. 
Most of the patients had asymmetrical FGR which concludes that there might be increased utero-placental resistance because of foetal growth restriction.

\section{DISCUSSION}

In the present study, 500 patients in first trimester of pregnancy were selected in this study. 400 patients were found to have normal levels and were followed up till delivery. 20 patients developed preterm labour. Out of 100 patients who had low PAPP-A level, 35 patients had developed preterm labour. 15 patients out of 400 normal patients developed foetal growth retardation, 13 out of 100 low patients had foetal growth retardation. 5 out 400 normal patients developed PIH and no still birth was seen in normal patients. 15 out of 100 low patients had PIH and 2 patients had still birth. Most of the patients had asymmetrical FGR which concludes that there might be increased utero-placental resistance because of foetal growth restriction.

Malik $\mathbf{J}$ et al conducted a study in which every patient visiting the antenatal OPD was counseled for testing of first trimester screening to assess fetal wellbeing. ${ }^{6} 524$ patients were included in the study, out of which 452 patients were found to have a normal PAPP -A level of $>0.5 \mathrm{MoM}$. All these patients were followed further during the antenatal period where 18 patients developed preterm labour and few patients developed pregnancy induced hypertension (PIH). The obstetric outcome of patients with normal PAPP-A level was fairly uneventful as compared to others with a low PAPP-A level. Kirkagard I et al reported that pregnancy-associated plasma protein-A (PAPP-A) is highly efficient as a serum marker in first-trimester screening for chromosomal abnormalities. ${ }^{7}$ Furthermore, there is increasing evidence that low levels of PAPP-A in the first trimester are associated with adverse pregnancy outcomes such as preterm delivery, intrauterine growth retardation, preeclampsia, and stillbirth. PAPP-A is a glycoprotein, produced in the placenta, and it is present in the maternal circulation in increasing concentrations during pregnancy. By means of its proteolytic activity, PAPP-A functions as a regulatory protein in the insulinlike growth factor system, known to be important for placental formation and regulation of fetal growth. This overview describes aspects of biochemistry, synthesis, and biological functions of PAPP-A, with a focus on information of importance to clinicians. The clinical applications of PAPP-A are summarized, and new insights regarding the analyses of PAPP-A discussed. Cowans NJ et al reported that ADAM12 and PAPP-A concentrations were reduced in low for gestational age birth weights and in all births with weights below 2.5 $\mathrm{kg} .{ }^{8}$ There was a linear relationship between the severity of the IUGR and the decrease in PAPP-A and ADAM 12. In the larger babies, only ADAM12 was found to be significantly increased in babies above the 90th centile of weight for gestation. Dugoff $\mathrm{L}$ et al reported that women with pregnancy-associated plasma protein A of $\leq 5$ th percentile were significantly more likely to experience spontaneous fetal loss at $\leq 24$ weeks of gestation, low birth weight, preeclampsia, gestational hypertension, preterm birth $(\mathrm{P}<0.001)$ and stillbirth, preterm premature rupture of membranes, and placental abruption $(\mathrm{P}<0.02) .^{9}$ Nuchal translucency at $\geq 99$ th percentile and free-beta subunit human chorionic gonadotropin at $\leq 1$ st percentile were associated with an increased risk of spontaneous loss at $\leq 24$ weeks of gestation (adjusted odds ratios, 3.90, 3.62, respectively; P <0.001). Crosley EJ et al Recent studies have consistently found pregnancy-associated plasma protein A2 (PAPP-A2) to be upregulated in preeclamptic placentae at term. ${ }^{10} \mathrm{We}$ tested whether first-trimester circulating PAPP-A2 levels differed between complicated and uncomplicated pregnancies. We measured maternal PAPP-A2 levels at 10 to 14 weeks of gestational age in 17 pregnancies resulting in small-forgestational-age (SGA) infants, 6 which developed preeclampsia (PE), 1 which developed $\mathrm{PE}$ and resulted in an SGA infant, and 37 gestational age-matched controls. The concentration of the PAPP-A2 isoform corresponding to the full-length protein was significantly higher in pregnancies that developed PE $(35 \mathrm{ng} / \mathrm{mL})$ compared with those that did not $(23 \mathrm{ng} / \mathrm{mL}$; P <0.044). In contrast, we found no difference in PAPP-A2 levels between pregnancies that did or did not result in an SGA infant. The upregulation of PAPP-A2 that has previously been observed in PE at term appears to begin early in pregnancy, well before the symptoms develop.

\section{CONCLUSION}

In the first trimester of pregnancy, PPP-A level is an important predictor of outcome of obstetrics. A low level of PAPP-A is useful in indicating the risk of pre-term delivery and chance of PIH development.

\section{Funding: No funding sources \\ Conflict of interest: None declared}

Ethical approval: The study was approved by the Institutional Ethics Committee

\section{REFERENCES}

1. Wang J, Qiu Q, Haider M, Bell M, Gruslin A, Christians JK. Expression of pregnancy-associated plasma protein A2 during pregnancy in human and mouse. J Endocrinol. 2009;202(3):337-45.

2. Yan X, Baxter RC, Firth SM. Involvement of pregnancy- associated plasma protein-A2 in insulinlike growth factor (IGF) binding protein-5 proteolysis during pregnancy: a potential mechanism for increasing IGF bioavailability. J Clin Endocrinol Metab. 2010;95(3):1412-20.

3. Christians JK, Gruslin A. Altered levels of insulinlike growth factor binding protein proteases in preeclampsia and intrauterine growth restriction. Prenat Diagn. 2010;30(9):815-20. 
4. Wagner PK, Otomo A, Christians JK. Regulation of pregnancy- associated plasma protein A2 (PAPPA2) in a human placental tro- phoblast cell line (BeWo). Reprod Biol Endocrinol. 2011;9:48.

5. Kramer A, Hoffman C, Lynch A, Winn VD. Maternal serum PAPP-A2 levels are elevated in early onset preeclampsia at time of diagnosis and in early gestation. Reprod Sci. 2012;19(3 suppl):87A.

6. Jyoti Malik, Pinki Raj, Ashima Das, Sibadatta Das; Pregnancy-associated plasma protein A - a level in first trimester and its impact on pregnancy outcome. Int J Reprod Contracept Obstretrics Gynaecol. 2016Aug;5(8):2680-3.

7. Kirkagard I, Uldberg N, Oxvig C. Biology of pregnancy associated plasma protein-a in relation to prenatal diagnostics; an overview. Acta obstet Gynecol Scand. 2010;89(9):1118-25.

8. Cowans NJ, Spencer K. First trimester ADAM 12 and PAPP-A as markers for intrauterine fetal growth restriction through their roles in the insulin like growth factor system. Prenat Diagn. 2007;27(3):26471.

9. Dugoff L, Hobbins JC, Malone FD. First trimester maternal serum PAPP-A and free beta Aubunit human chorionic gonadotrophin concentrations and nuchal translucency are associated with obstetric complications: a population based screening study (the faster trial). Am J Obstet Gynecol. 2004;19(6):1446-51.

10. Crosley EJ, Durland U, Seethram K, MacRae S, Gruslin A, Christians JK. First-trimester levels of pregnancy-associated plasma protein A2 (PAPP-A2) in the maternal circulation are elevated in pregnancies that subsequently develop preeclampsia. Reprod Sci. 2014 Jun;21(6):754-60.

Cite this article as: Devi VR. Associated plasma protein during the first trimester of pregnancy and pregnancy outcomes. Int J Reprod Contracept Obstet Gynecol 2018;7:448-51. 